\title{
Treatment of type 2 diabetes in Latin America: a consensus statement by the medical associations of 17 Latin American countries
}

\author{
Juan Rosas Guzmán, ${ }^{1}$ Ruy Lyra, ${ }^{2}$ Carlos A. Aguilar-Salinas, ${ }^{3}$ \\ Saulo Cavalcanti, ${ }^{4}$ Felix Escaño, ${ }^{5}$ Marcos Tambasia, ${ }^{6}$ \\ Elizabeth Duarte, ${ }^{7}$ and the ALAD Consensus Group ${ }^{1}$
}

Suggested citation

Guzmán JR, Lyra R, Aguilar-Salinas CA, Cavalcanti S, Escaño F, Tambasia M, et al. Treatment of type 2 diabetes in Latin America: a consensus statement by the medical associations of 17 Latin American countries. Rev Panam Salud Publica. 2010;28(6):463-71.

\begin{abstract}
Latin America faces unique challenges in the treatment of type 2 diabetes mellitus. The Asociación Latinoamericana de Diabetes (Latin American Diabetes Association, ALAD) brought together medical associations in 17 countries in Latin America to produce a consensus statement regarding the treatment of type 2 diabetes. The goal of the document is to provide practical recommendations that will guide clinicians through a simple decision-making process for managing patients. The cornerstone elements for therapeutic decision making are: severity of hyperglycemia, clinical condition of the patient (stable or with metabolic decompensation), and body mass index. The consensus includes a section devoted specifically to patients with obesity. Information is presented as highly-relevant clinical questions. The algorithm is based on the scientific recommendations of the 2006 ALAD guidelines (a document prepared using an evidence-based approach) and data from recent randomized controlled studies.
\end{abstract}

Key words Diabetes mellitus, type 2; obesity; consensus; practice guidelines as topic; Latin America.

Latin America is undergoing a remarkable epidemiological transformation. Diabetes and other chronic, nontransmissible diseases are now the leading health problems. Despite the

\footnotetext{
1 Asociación Latinoamericana de Diabetes, Celaya, Guanajuato, México.

2 Federación Panamericana de Endocrinologia, Pernambuco, Brazil.

3 Sociedad Mexicana de Nutrición y Endocrinología. México City, Mexico. Send correspondence to Carlos Alberto Aguilar-Salinas, caguilarsalinas@yahoo. com.

4 Sociedade Brasileira de Diabetes, São Paulo, Brazil.

5 Sociedad Dominicana de Endocrinología, Santo Domingo, República Dominicana.

6 Sociedade Brasileira de Endocrinologia e Metabologia, Rio de Janeiro, Brazil.

7 Sociedad Boliviana de Endocrinología, Metabolismo y Nutrición, La Paz, Bolivia.
}

large and growing number of diabetes cases, this geographic area invests limited financial resources in diabetes care. Indeed, diabetes prevalence in several Latin American countries is among the highest in the world, e.g., Mexico at $14.4 \%$ (1). In the year 2000, the direct cost of diabetes care in Latin America and the Caribbean was approximately US\$ 10 billion; minimal when compared to the indirect cost of about US\$ 55 billion resulting from disease-related consequences. In 2000, the total diabetes-related annual cost in Latin America and the Caribbean was US\$ 65 billion-US\$ 15 billion in Mexico, US\$ 2.6 billion in Central America, and US\$ 44.4 billion in South America.
In Latin America, families pay about $40 \%-60 \%$ of diabetes costs out-of-pocket. Most private health insurance plans cover medical assistance, procedures, and hospitalization, but not medication (2-5). The burden of disease will be even greater in the coming years because the population has a large proportion of young adults living in urban areas and engaged in unhealthy lifestyles. Thus, the impact of diabetes in Latin America is growing fast and the national health systems are unprepared.

Latin America urgently needs to reorganize its health care services from a system designed to treat acute infectious disorders to one focused on behavior 
modification, long-term treatment adherence, and achievement of therapeutic goals. Such restructuring should be based on the best available clinical evidence, but existing international guidelines should be adapted to reflect the differences and needs of each geographic area. The unique challenges regarding type 2 diabetes treatment in Latin America are a result of the interactions among the area's socioeconomic factors, its variety of cultures and traditions, and its limited health resources. Consensus documents and practice guidelines that are specifically oriented toward the Latin American environment are needed to train and guide primary care physicians.

\section{CONSENSUS METHODOLOGY}

The Asociación Latinoamericana de Diabetes (the Latin American Diabetes Association, ALAD) is committed to medical education throughout Latin America. In line with its commission, ALAD called upon leaders and representatives from the endocrine and diabetes associations of 17 countries in Latin America to produce a consensus statement for the treatment of type 2 diabetes mellitus.

Participants received background information prior to a face-to-face meeting. The participants were divided into three groups; each group discussed and responded to three of the nine questions addressed by the present report. Conclusions were presented by each group to the audience, made up of the other two groups; each recommendation was discussed until unanimous agreement was reached. A writing committee prepared the summary, which was approved by all of the endorsing associations' representatives. The final version of the document was prepared and approved by the members of the writing committee.

The aim of the meeting was to create feasible recommendations that could be put into practice quickly by the participating countries. The algorithm was based on the scientific recommendations of the 2006 ALAD guidelines-a document prepared using an evidence-based approach (6) - and data from recent randomized controlled studies. The principal conclusions of the document (e.g., treatment goals) are in accordance with the recommendations of the American Diabetes Association of the United States of America.

\section{CONSENSUS STRUCTURE}

An algorithm to guide the treatment of hyperglycemia was constructed that takes into account the glycemic status of the patient. Special emphasis was placed on the most common clinical situations. Also included in this algorithm were the possible clinical scenarios diabetes patients may present and the necessary actions to follow in each case. Additionally, two groups of patients-divided according to the level of glycemic control and clinical condition-are included:

Group 1. Patients with blood glucose levels < $240 \mathrm{mg} / \mathrm{dL}$ (13.3 mmol/L), $\mathrm{HbA}_{1 \mathrm{c}}<9 \%$, and clinically stable.

Group 2. Patients with blood glucose levels $\geq 240 \mathrm{mg} / \mathrm{dL}(13.3 \mathrm{mmol} / \mathrm{L})$, $\mathrm{HbA}_{1 \mathrm{c}} \geq 9$, and:

a. with few symptoms, no ketosis.

b. catabolic-symptomatic, weight loss, and ketosis-prone.

The cornerstone elements for therapeutic decision-making presented in this document are: severity of hyperglycemia, the clinical condition of the patient (stable or with metabolic decompensation), and body mass index (BMI). The Consensus includes a section specifically aimed at patients with obesity. These patients constitute a therapeutic challenge; primary care units do not have the resources to manage such cases. Without a multidisciplinary approach and adequately informed medical personnel, patients, and relatives, obese patients with diabetes frequently continue gaining weight and do not achieve treatment goals. Counseling for behavior modification is fundamental in these cases. The section on obesity emphasizes the importance of helping patients follow a healthy lifestyle before and during the escalation of pharmacological treatment. It is hoped that this resource be made available in every primary care center.

\section{THE CONSENSUS STATEMENT}

The clinical recommendations for treatment of type 2 diabetes in Latin America are presented as clinical questions:

\section{What are the treatment goals for the patient with type 2 diabetes?}

Glycemic control is fundamental to the management of diabetes. In type 2 diabetes, the Kumamoto study (7) and the United Kingdom Prospective Diabetes Study (UKPDS) $(8,9)$ demonstrated significant reductions in $\mathrm{mi}$ crovascular and neuropathic complications with intensive therapy. Similar to the Diabetes Control and Complications Trial-Epidemiology of Diabetes Interventions and Complications (DCCTEDIC) studies' findings (10), long-term follow-up of the UKPDS cohort has recently demonstrated a "legacy effect" of early, intensive glycemic control on long-term rates of microvascular complications. This benefit continues, even if the differences in glycemic control between the intensive and standard cohorts are lost after the end of the study $(10,11)$. In Latin America, fasting blood glucose (venous or capillary) values are the key elements used by physicians to evaluate their patients and guide decisions. However, in line with other scientific organizations (12-14), glycosylated hemoglobin $\left(\mathrm{HbA}_{1 \mathrm{c}}\right)$ is recommended as the optimal method to assess glycemic control. As shown in Table 1, $\mathrm{A}_{1 \mathrm{c}}$ levels can be translated to mean plasma glucose concentrations, making it easier for patients to understand the information. In several large, randomized, prospective clinical trials, treatment regimens that reduced $A_{1 C}<7 \%$ were associated with fewer long-term microvascular complications. Whereas many studies and meta-analyses (15-17) have shown a direct relationship between $\mathrm{A}_{1 \mathrm{C}}$ and the incidence of cardiovascular events, the potential of intensive glycemic control to reduce cardiovascular mortality has been less clearly defined. Based on current clinical evidence (18-21), an $\mathrm{HbA}_{1 \mathrm{c}}$ $<7 \%$ is recommended as the most appropriate level for the majority of patients. However, in certain situations this objective must be customized. For example, in young patients with no evidence of complications and no major risk of hy-

TABLE 1. Relationship between blood glucose levels and Hemoglobin $A_{1 c}\left(H b A_{1 c}\right)$

\begin{tabular}{|c|c|c|}
\hline \multicolumn{2}{|c|}{ Mean blood glucose levels } & \multirow{2}{*}{$\begin{array}{c}\mathrm{HbA}_{1 \mathrm{c}} \\
(\%)\end{array}$} \\
\hline $\mathrm{mg} / \mathrm{dL}$ & $\mathrm{mmol} / \mathrm{L}$ & \\
\hline 345 & 19.5 & 12 \\
\hline 310 & 17.5 & 11 \\
\hline 275 & 15.5 & 10 \\
\hline 240 & 13.5 & 9 \\
\hline 205 & 11.5 & 8 \\
\hline 170 & 9.5 & 7 \\
\hline 135 & 7.5 & 6 \\
\hline
\end{tabular}


TABLE 2. Proposed treatment goals for patients with type 2 diabetes in Latin America, 2010

\begin{tabular}{|c|c|c|}
\hline Parameter & Targets & Unit \\
\hline Fasting blood glucose & $70-120$ & $\mathrm{mg} / \mathrm{dL}(3.8-6.6 \mathrm{mmol} / \mathrm{L})$ \\
\hline 2-hour post-prandial glucose & $<140$ & $\mathrm{mg} / \mathrm{dL}(7.7 \mathrm{mmol} / \mathrm{L})$ \\
\hline Hemoglobin $\mathrm{A}_{1 \mathrm{C}}$ & $<7$ & $\%$ \\
\hline \multirow[t]{2}{*}{ LDL $^{a}$ cholesterol } & $<100$ & $\mathrm{~m} / \mathrm{dL}(2.6 \mathrm{mmol} / \mathrm{L})$ \\
\hline & $<70^{\mathrm{b}}$ & $\mathrm{mg} / \mathrm{dl}(1.8 \mathrm{mmol} / \mathrm{l})$ \\
\hline HDL $^{\mathrm{c}}$ cholesterol (both genders) & $>40$ & $\mathrm{mg} / \mathrm{dL}(1.05 \mathrm{mmol} / \mathrm{L})$ \\
\hline Triglycerides & $<150$ & $\mathrm{mg} / \mathrm{dL}(1.68 \mathrm{mmol} / \mathrm{L})$ \\
\hline \multirow[t]{2}{*}{ Microalbuminuria } & $<30$ & $\mathrm{mcg} / \mathrm{g}$ creatinine (spot sample) \\
\hline & $<30$ & mg/day (24-hour urine sample) \\
\hline Blood pressure & $\leq 130 / 80$ & $\mathrm{~mm} / \mathrm{Hg}$ \\
\hline Body mass index & $>19-<25$ & $\mathrm{~kg} / \mathrm{m}^{2}$ \\
\hline
\end{tabular}

a Low density lipoproteins.

${ }^{b}$ With cardiovascular disease or at high risk (defined as the presence of one or more cardiovascular risk factors).

${ }^{\mathrm{c}}$ High density lipoproteins.

poglycemia, an $\mathrm{HbA}_{1 \mathrm{c}}$ value $<6.5 \%$ may be considered.

In addition, this Consensus highlights plasma lipid and blood pressure goals as prominent objectives of diabetes man- agement (Table 2). Several controlled studies and meta-analyses have shown the benefits of lipid lowering therapies in patients with diabetes. The same is true for antihypertensive therapy. The review of the supporting evidence is beyond the scope of this document.

Finally, the panel recommended the inclusion of microalbuminuria as a treatment target. The concentration of microalbuminuria should be measured annually in all type 2 diabetes patients and in type 1 diabetes patients with disease duration $\geq 5$ years. Microalbuminuria should be treated by achieving blood pressure targets; the use of angiotensinconverting enzyme (ACE) inhibitors inhibitors and angiotensin II receptor blockers have been shown to delay the progression to macroalbuminuria.

Figure 1 demonstrates the modifications advocated for ALAD's 2006 type 2 diabetes mellitus treatment algorithm (6). Non-pharmacological recommendations are summarized in Table 3. Drugs currently used in diabetic care, including mean and maximum doses are described

FIGURE 1. Latin American Diabetes Association recommendations for the management of hyperglycemia in patients with type 2 diabetes, 2010

Fasting glucose $\geq 126 \mathrm{mg} / \mathrm{dL}(7 \mathrm{mmol} / \mathrm{L})$ to $<240 \mathrm{mg} / \mathrm{dL}(13.3 \mathrm{mmol} / \mathrm{L})$ and/or $\mathrm{HBA} \mathrm{fc}_{1 \mathrm{c}}<9 \%$

\section{Start lifestyle change (LSC) + Metformin (MET)}

If MET is contraindicated, or not tolerated, consider any of the following antidiabetic medications: tiazolidinedione (TZD), DPP-4 inhibitors (DPP-4 INH), sulfonylurea (SU) (especially if body mass index

$(\mathrm{BMI})<27 \mathrm{~kg} / \mathrm{m}^{2}$ ), meglitinides (especially in presence of high postprandial blood glucose), acarbose (if postprandial blood glucose is high, but fasting glucose is $<180 \mathrm{mg} / \mathrm{dL}$ and/or $\mathrm{HbA}_{1 \mathrm{c}}<7.5 \%$ )
Fasting glucose $\geq 240 \mathrm{mg} / \mathrm{dL}$ (13.3 $\mathrm{mmol} / \mathrm{L}$ ) and/or $\mathrm{HBA}_{1 \mathrm{c}} \geq 9 \%$
-Clinically stable with no ketoacidosis
-Clinically unstable -Prone to ketoacidosis -Weight loss

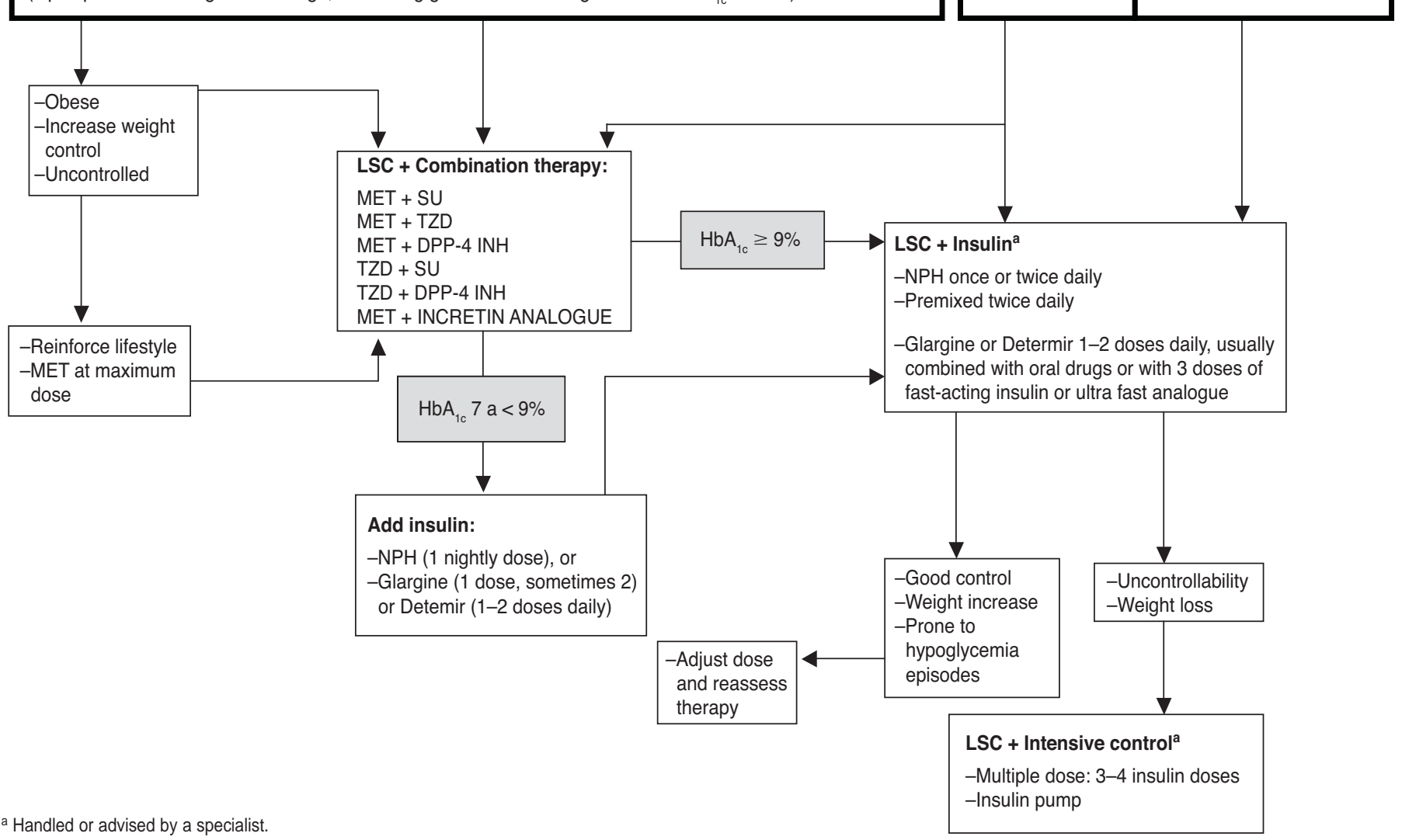


TABLE 3. Lifestyle recommendations to prevent and treat type 2 diabetes mellitus in Latin America, 2010

A. Education is the most important factor in the treatment of diabetes mellitus. Patients and their families should receive well-defined information to educate and empower them to make the right choices concerning lifestyle.

B. Aerobic physical activities should be performed for at least 30 minutes, 5 days/week, according to each patient's characteristics. Anaerobic activities could be considered as complementary.

C. Nutritional medical therapy should be customized according to the baseline body mass index and physical activity level of each patient. Macronutrient content of the diet should be adjusted to $50 \%-60 \%$ carbohydrates; $20 \%-30 \%$ fat with less than $7 \%$ saturated fat; and 10\%-20\% protein (minimum $1 \mathrm{~g} / \mathrm{kg}$ of ideal weight per day)

D. Natural fiber intake should be $20-30 \mathrm{~g} /$ day.

E. Daily salt intake should be $<5 \mathrm{~g}$ in patients with diabetes and $<3 \mathrm{~g}$ in patients with associated hypertension.

F. Diet should consider availability and patient preference, while minimizing the use of processed foods.

G. Alcohol consumption should be discouraged.

H. Tobacco should not be allowed.

TABLE 4. Medications currently approved to treat type 2 diabetes, 2010

\begin{tabular}{llrr}
\hline \multicolumn{1}{c}{ Class } & \multicolumn{1}{c}{ Drugs } & $\begin{array}{c}\text { Mean daily } \\
\text { doses }\end{array}$ & $\begin{array}{r}\text { Maximum daily } \\
\text { doses }\end{array}$ \\
\hline Biguanide & Metformin & $850 \mathrm{mg}^{\mathrm{a}}$ & $2550 \mathrm{mg}$ \\
Sulfonylureas & Chlorpropamide & $250 \mathrm{mg}^{\mathrm{b}}$ & $500 \mathrm{mg}$ \\
& Glibenclamide & $5 \mathrm{mg}^{\mathrm{a}}$ & $20 \mathrm{mg}$ \\
& Glipizide & $5 \mathrm{mg}^{\mathrm{a}}$ & $20 \mathrm{mg}$ \\
& Glimepiride & $4 \mathrm{mg}^{\mathrm{b}}$ & $8 \mathrm{mg}$ \\
& Gliclazide & $80 \mathrm{mg}^{\mathrm{a}}$ & $320 \mathrm{mg}$ \\
Meglitinides & Gliclazide MR & $60 \mathrm{mg}^{\mathrm{b}}$ & $120 \mathrm{mg}$ \\
& Nateglinide & $60 \mathrm{mg}^{\mathrm{c}}$ & $360 \mathrm{mg}$ \\
Thiazolidinediones & Repaglinide & $2 \mathrm{mg}^{\mathrm{c}}$ & $12 \mathrm{mg}$ \\
& Rosiglitazone & $4 \mathrm{mg}^{\mathrm{a}}$ & $8 \mathrm{mg}$ \\
\multirow{3}{*}{$\alpha$-glucosidase inhibitors } & Pioglitazone & $30 \mathrm{mg}^{\mathrm{b}}$ & $45 \mathrm{mg}$ \\
& Acarbose & $50 \mathrm{mg}^{\mathrm{c}}$ & $300 \mathrm{mg}$ \\
DPP-4 inhibitors/gliptines & Miglitol & $25 \mathrm{mg}^{\mathrm{c}}$ & $100 \mathrm{mg}$ \\
& Sitagliptin & $100 \mathrm{mg}^{\mathrm{b}}$ & $100 \mathrm{mg}$ \\
& Vildagliptin & $50 \mathrm{mg}^{\mathrm{a}}$ & $100 \mathrm{mg}$ \\
Incretine analogues & Saxaglipnin & $5 \mathrm{mg}^{\mathrm{b}}$ & $5 \mathrm{mg}$ \\
& & & \\
& Exenatide & $20 \mathrm{mcgr}^{\mathrm{a}}$ & $20 \mathrm{mcgr}$ \\
& Liraglutide & $1.2 \mathrm{mg}^{\mathrm{b}}$ & $1.8 \mathrm{mg}$ \\
\hline
\end{tabular}

aTwice a day.

${ }^{b}$ Once a day.

cThree times a day.

TABLE 5. Characteristics of insulin preparations used in Latin America, 2010

\begin{tabular}{lccc}
\hline \multicolumn{1}{c}{ Insulin } & Start of action & Peak & Duration \\
\hline Regular human insulin & $30-60 \mathrm{~min}$ & $2-3 \mathrm{hr}$ & $6-8 \mathrm{hr}$ \\
Aspart & $10-20 \mathrm{~min}$ & $1-2 \mathrm{hr}$ & $3-5 \mathrm{hr}$ \\
Lispro & $5-15 \mathrm{~min}$ & $0.5-1.5 \mathrm{hr}$ & $4-6 \mathrm{hr}$ \\
Glulisine & $5-10 \mathrm{~min}$ & $1-2 \mathrm{hr}$ & $3-4 \mathrm{hr}$ \\
NPH insulin & $2-4 \mathrm{hr}$ & $4-10 \mathrm{hr}$ & $12-18 \mathrm{hr}$ \\
Glargine & $2-4 \mathrm{hr}$ & $\mathrm{No}$ & $24 \mathrm{hr}$ \\
Detemir & $0.8-2 \mathrm{hr}$ & $\mathrm{No}$ & $24 \mathrm{hr}$ \\
Biphasic human $70 / 30$ & $0.5-1 \mathrm{hr}$ & $2-4$ and 6-12 hr & $16-22 \mathrm{hr}$ \\
Biphasic aspart 70/30 & $5-15 \mathrm{~min}$ & $1-2$ and 6-12 hr & $16-22 \mathrm{hr}$ \\
Biphasic lispro 75/25 & $5-15 \mathrm{~min}$ & $1-2$ and 2-12 hr & $16-22 \mathrm{hr}$ \\
Biphasic lispro 50/50 & $5-15 \mathrm{~min}$ & $1-2$ and 6-12 hr & $16-22 \mathrm{hr}$ \\
\hline
\end{tabular}

in Table 4. The pharmacological characteristics of insulin preparation and insulin analogues are included in Table 5.

\section{How should a clinically-stable patient with type 2 diabetes with mean fasting glycemia $<240 \mathrm{mg} / \mathrm{dL}(13.3 \mathrm{mmol} / \mathrm{L})$, and $\mathrm{HbA}_{1 \mathrm{c}}<9 \%$ be managed?}

Most individuals with type 2 diabetes show few clinical signs or symptoms at onset. This is why many patients are diagnosed late. If the patient is clinically stable, has few symptoms, no ketosis, fasting blood glucose between $126 \mathrm{mg} / \mathrm{dL}$ (7 $\mathrm{mmol} / \mathrm{L})$ and $240 \mathrm{mg} / \mathrm{dL}(13.3 \mathrm{mmol} / \mathrm{L})$ and/or $\mathrm{HbA}_{1 \mathrm{c}}<9 \%$, the cornerstone of treatment is the initiation of a healthy lifestyle with adequate nutrition, regular exercise, and cessation of smoking, if applicable. Alcohol consumption should be limited to 1 drink/day for adult women and 2 drinks/day for adult men.

In addition, Metformin (500 mg $3 \times$ / day) should be started in all patients, and can be gradually increased to $2.5 \mathrm{~g} /$ day, as needed, to achieve the treatment goal in a 3-month period. Besides its therapeutic effects, Metformin has been shown to decrease cardiovascular complications in retrospective $(22,23)$ and prospective analyses $(8,9)$ and has the advantage of being easily accessible for virtually all populations. Metformin dose should be reduced in patients with an estimated glomerular filtration rate (eGFR) $<60 \mathrm{~mL} / \mathrm{min}$. The drug is contraindicated if the eGFR is $<30 \mathrm{~mL} / \mathrm{min}$. The eGFR can be estimated by using the Cockcroft-Gault formula (24) or the MRDS equation used in the Diet in Renal Disease Study-recommended by the National Kidney Disease Education Program (United States, 25). Likewise, Metformin is contraindicated in patients with alcoholism, severe chronic obstructive pulmonary disease (COPD), and/or decompensated heart, respiratory, or liver failure (26).

If Metformin is contraindicated, or in case of gastrointestinal intolerance, the following options may be considered for monotherapy (27):

(a) Sulfonylureas: These are among the most effective oral drugs, with robust clinical experience and low cost. However, the risk of hypoglycemia (especially with first generation, longacting sulfonylureas) and weight gain should be considered (28). The efficacy of sulfonylureas over the long- 
term is less than that of Metformin and glitazones.

(b) Meglitinides: These drugs are particularly useful when post-prandial hyperglycemia is the main abnormality. Due to their short half-life, meglitinides can be used in patients with renal failure (29).

(c) Glitazones: Insulin resistance and inflammatory markers are decreased with glitazone therapy. Patients should be carefully selected for this therapeutic option in order to reduce the risk of heart failure, coronary events, or fractures (particularly in postmenopausal women) (30).

(d) Acarbose: Its main effect is on postprandial glycemia. Acarbose reduces $\mathrm{A}_{1 \mathrm{c}}$ values by $0.5 \%$. Gradual titration helps improve gastrointestinal tolerance (31).

(e) DPP-IV inhibitors or gliptins: These recently launched drugs prevent the inactivation of Glucagon-like peptide 1 (GLP-1) by inhibiting the enzyme dipeptidyl peptidase-4 (DPP-IV). Therefore, gliptins enhance and prolong the action of the endogenously released GLP-1. DPP-IV inhibitors reduces $\mathrm{A}_{1 \mathrm{c}}$ values by $0.5-0.9 \%$. Gliptins are orally active, safe, and highly tolerable, with a minimal risk for hypoglycemic events. They are body weight neutral. These drugs have been used in combination with Metformin, sulfonylureas, and thiazolidinediones. However, additional evidence is required to assess the long-term effects of the DPP-IV inhibitors, in particular issues such as safety and their effectiveness in the prevention of the diabetes-related chronic complications (32).

(f) GLP-1 analogues: These drugs (exenatide and liraglutide) were introduced to the Latin American markets during 2009. GLP-1 increases insulin output and decreases glucagon secretion in a glucose-dependent manner. Therefore, the risk of hypoglycemia is minimal. One year results show that their use improves $\mathrm{A}_{1 \mathrm{c}}$ levels (-0.79 to $\left.-1.12 \%\right)$ and both fasting and post-prandial hyperglycemia; in addition, a moderate weight loss effect occurs. GLP-1 analogues promote weight loss through the gastrointestinal side-effects and also by slowing gastrointestinal motility and inducing satiety. However, the need for daily subcuta- neous administration and their side effects (i.e., nausea and gastrointestinal symptoms) may limit their use. Additional evidence is required to assess the long-term effects of the GLP-1 analogues in the prevention of diabetes-related chronic complications and long term safety $(33,34)$.

Public and private institutions should decide which of these drugs should be used as the first option. The decision should be based on cost-effectiveness analysis and individualized patient care.

\section{What should be done if mono- therapy fails?}

The patient should reach treatment goals $\left(\mathrm{HbA}_{1 \mathrm{c}}<7 \%\right)$ within 3 months of monotherapy. If this is not so, combination therapy should be initiated. Combinations shown to be useful are listed in Table 6 . The most widely-used combination in Latin America is Metformin plus Sulfonylurea. This combination provides good therapeutic efficacy. Other options based on Metformin may also be considered at this stage: Metformin + Meglitinides, Metformin + Glitazones, Metformin + DPP-4 inhibitors, and Metformin + Incretin Analogues (6, 28, $35,36)$. Less popular combinations (e.g., Sulfonylureas with Glitazones, Glitazones with DPP-4 inhibitors, Acarbose with Sulfonylureas, Metformin + Acarbose, and Sulfonylureas with DPP-4 inhibitors may be useful in certain situations due to their synergistic mechanism of action; however, the evidence that supports their use is not as strong as that for conventional combinations.

Combination therapy with three drugs is indicated in some patients (37). Options include the use of DPP-IV inhibitors, GLP-1 analogue, or glitazones, in addition to Metformin and a sulfony-

TABLE 6. Successful combination of oral antihyperglycemic agents with their evidencebased recommendation for patients with type 2 diabetes, 2010

\begin{tabular}{lc}
\hline \multicolumn{1}{c}{ Combination } & Recommendation \\
\hline Metformin + Sulfonylurea & A \\
Metformin + Glitazone & A \\
Metformin + Acarbose & B \\
Metformin + Meglitinide & B \\
Sulfonylurea + Glitazone & B \\
Sulfonylurea + Acarbose & B \\
Gliptines + Metformin & B \\
Meglitinida + Glitazona & B \\
\hline
\end{tabular}

Source: ALAD Guidelines (6). lurea. The intervention of a diabetes specialist could be considered in patients who are not reaching the treatment targets despite the use of three agents.

\section{What should be done to manage} overweight patients not controlled by monotherapy and who continue to gain weight?

Lack of adherence to a healthy lifestyle is a contributing factor to not achieving treatment goals in the clinically-stable obese patient with a $\mathrm{HbA}_{1 \mathrm{c}}<9 \%$ (38). These patients require closer monitoring and the support of a multidisciplinary team, if available, for the implementation of an adequate dietary plan, an exercise program, and psychological support. In addition, Metformin dosage should be titrated to reach its maximal effect. The use of combination therapy that may provoke weight gain should be limited to cases that remain hyperglycemic despite lifestyle modifications. The timeframe for considering combination therapy will depend on the patient's circumstances (39).

5. What should be done when treatment goals are not achieved with an oral combination?

Failure to achieve treatment goals on combination therapy, despite using drugs with differing mechanisms of action, indicates a significant deficit in insulin production. This is due to the progressive decline in insulin secretory capacity that occurs in type 2 diabetes. To meet $\mathrm{HbA}_{1 \mathrm{c}}$ goals, insulin therapy will be necessary in such patients. Initially, control can be achieved with a bedtime dose of Neutral Protamine Hagedorn (NPH) insulin or a long-acting insulin analogue (Glargine or Detemir) in combination with oral agents. Glargine can be given at any moment of the day.

Under this treatment scheme, insulin dosage should be regularly titrated based on fasting glycemia. Changes in dosage should not be greater than $10 \%$ of the total dose. The frequency of the adjustments depends on the patient characteristics and the experience of the practitioner. Changes in the dosage on a daily basis may be necessary in severely hyperglycemic patients. When the treatment goals are close to being achieved, it is better to adjust the amount of insulin every 3-4 days. Frequent and large changes in dosage may cause recurrent hypoglycemia and weight gain. A time period of at least 1-3 months is recom- 
mended to assess whether treatment goals are achieved before considering a change in treatment regime. With time, progression to full insulinization will be necessary. Of note, the combination of insulin with glitazones is not recommended due to the increased risk of edema and heart failure.

Other management alternatives are available for intensifying insulin therapy. The choice depends on insulin availability, patient requirements, metabolic behavior, and risk of hypoglycemia. One option is a mixture of 2 types of insulin, such as regular insulin and $\mathrm{NPH}$ insulin, or a combination of a short acting insulin analogue (Lispro, Aspart, or Glulisine) with NPH insulin. The mixtures may be prepared by the patient or fixed-dose preparations can be used. Premixes can be selected at a ratio of $30: 70,25: 75$, or other less common proportions. Another option is 1-2 doses of a long-acting analogue (Glargine or Detemir) with a dose of regular human insulin or a rapid-acting insulin analogue before each meal. Time of action, peak activity, and duration of different insulins and insulin analogues are shown in Table $5(40,41)$. At this stage of intensive insulin therapy, referral of the patient to a specialist is recommended.

\section{How should a clinically unstable pa-} tient with type 2 diabetes be managed? For patients with few clinical symptoms, no weight loss or ketosis, the prescription of oral combination therapy is recommended. This can rapidly correct the metabolic state, reduce glucotoxicity, and correct fasting/post-prandial glycemia and $\mathrm{HbA}_{1 \mathrm{c}}$. If there is a lack of response after a 1-3 month period, patients should be started on an insulin regimen (42).

Symptomatic patients who are losing weight rapidly or are ketotic should receive insulin therapy immediately. Any of the insulin regimens described above is useful for the prompt correction of hyperglycemia and nutritional status (43). Later, once these patients are stable and have regained weight, the treatment should be reassessed; the possibility of switching to oral drugs can be considered. This situation can occur especially in recent-onset diabetes. Other patients may need to be maintained on an insulin regimen. Some cases may be eligible for a more intensive therapeutic regimen with multiple insulin doses or an insulin pump. Such patients should always be treated by a specialist. It is assumed that measures for adopting a healthy lifestyle are in place and reinforced regularly.

\section{When should changes be made to the therapeutic regimen?}

The adoption of a healthy lifestyle is obligatory for the success of all treatment modalities. All therapeutic alternatives should be given a reasonable amount of time to evaluate their maximal efficacy. This is especially relevant if there is clinical improvement, weight stabilization, and gradual improvement of fasting and post-prandial glucose and $\mathrm{HbA}_{1 \mathrm{c}}$ values. A 1-3 month period is enough to reach expected benefits. The dosage should always be titrated based on monitoring of fasting/post-prandial glycemia. Primary care physicians are discouraged from delaying the addition of an oral glucoselowering agent or insulin. Clinical inertia is a contributing factor for not achieving treatment targets in all health systems.

\section{How should patients be monitored?}

Health care systems in Latin America do not have comprehensive multidisciplinary teams for the treatment of patients with diabetes. In most countries, the primary care physician is responsible for the treatment of a large proportion of the diabetic population. Physicians should instruct patients on how to self-monitor and manage their own health. Self-monitoring is a fundamental tool for all patients with diabetes; in particular, those on insulin treatment who require intensive glucose monitoring. A self-monitoring plan is a recommended component of patient management. It helps determine whether patients are on the right track for achieving treatment objectives (44). Capillary glucose measurement has become more accessible in Latin America; however, the high cost of glucometers and test strips is still a significant problem for many patients.

$\mathrm{HbA}_{1 \mathrm{c}}$ determination is recommended every 3-4 months. It must be taken into account, however, that this index is not readily available throughout Latin America, and where it is available, cost is often a deterrent.

\section{When should a diabetes specialist be consulted?}

The number of health professionals specifically trained to manage patients with diabetes is very limited in Latin America. General practitioners are often responsible for making treatment decisions during the early stages of the disease. They do this with limited resources and time constraints. However, it is essential that practitioners aim to achieve the standards of diabetes care in their patients. Continuing medical education for primary care physicians must be a priority for national and international medical institutes. Patients who do not achieve treatment goals within a 6-12 month period should be referred to a specialist. Likewise, those requiring intensive insulin regimens should be managed by a diabetologist/endocrinologist.

\section{DISCUSSION}

The health care systems of Latin American countries must be restructured to face the challenge that diabetes represents. Training of medical students and primary care physicians should be updated to provide the necessary skills for successfully implementing diabetes care and promoting long-term adherence to therapy (45). In addition, diabetes education programs are needed for both patients and the general public. These actions will create awareness about the disease and its consequences. This step is crucial to achieving sustained changes in lifestyle and adherence to therapy. If these actions are not implemented, a large percentage of the diabetic population will remain outside of the treatment target levels $(45,46)$.

The health care associations and institutes of Latin America should all be involved in creating a diabetes care action plan. They can prepare position documents that guide doctors in achieving better therapeutic results. They can also participate in the continuing education of health professionals $(47,48)$. Local guidelines are necessary.

Adopting recommendations prepared for other areas of the world may not be feasible due to economic, logistic, and/or cultural differences. Latin American countries share many ethnic, social, cultural, and lifestyle characteristics. As such, ALAD has produced specific recommendations for Latin America for the last 40 years. In 2006, ALAD published guidelines for the diagnosis, control, and treatment of the patient with type 2 diabetes, i.e., the "Guías ALAD de Diagnóstico, Control y Tratamiento de la Diabetes Mellitus tipo 2" (6). This document was approved and recommended by the Pan 
American Health Organization (PAHO) as guidelines for Latin America (49).

Since 2006, new strategies, medications, and information have arisen for various aspects of type 2 diabetes treatment. For this reason, ALAD called upon the national diabetes and/or endocrinology associations to produce a consensus document. The aim was to integrate the ALAD guidelines with important information from each organization to produce a common standard for diabetes in Latin America. The recommendations are applicable to practically every patient, with some possible exceptions. In summary, the document:

1. Acknowledges the importance of reaching treatment targets early, especially in the initial years of the disease. The document recommends an $\mathrm{HbA}_{1 \mathrm{c}}$ level below $7 \%$ as the target for glucose control. If the clinical condition of the patient allows, an $\mathrm{HbA}_{1 \mathrm{c}}$ goal of $\geq 6.5 \%$ should be considered.

2. Defines two clinical profiles that differ by $\mathrm{HbA}_{1 \mathrm{c}}$ levels, body weight, and the presence/absence of ketosis.

3. Includes special notes regarding obese patients who are unable to reach glucose treatment goals and continue to gain weight. This phenotype is often overlooked by other guidelines.

4. Recommends the early use of combination therapy and the timely addition of insulin in patients who do not achieve adequate glucose control. Also included are combinations with sufficient clinical evidence to support their use. Primary care physicians are discouraged from delaying the addition of an oral glucose lowering agent or insulin because this practice results in prolonged exposure to the adverse effects of hyperglycemia.

5. Describes clinical traits of the available glucose-lowering agents to aid in selecting from among the treatment options.

6. Recognizes that, in Latin America, logistics can limit the use $\mathrm{HbA}_{1 \mathrm{c}}$ determination-the gold standard for glycemic control-and offers regular determination of venous and capillary glycemia as an acceptable alternative. The position statement recommends treatment targets for both $\mathrm{HbA}_{1 \mathrm{c}}$ and fasting glucose levels. In addition, the importance of individual practitioners as providers of diabetes care in Latin America is highlighted. However, the need to create multidisciplinary groups is also reinforced.

7. Provides clinical indications and possible contraindications for all of the existing glucose lowering agents. None are excluded. It is the responsibility of each medical institute and ALAD to educate physicians to ensure correct medication usage.

8. Was prepared and approved by diabetes specialists/physicians, leaders, and experts in Latin America.

Although the evidence supporting current clinical recommendations is universal, the quality of diabetes care depends on geographic factors. Because this consensus takes into account the unique challenges faced by patients and physicians in Latin America, its strategies are more feasible and it is hoped that its impact will go farther than that of past efforts to improve diabetes management. Primary care physicians are the principal focus of this review. Special emphasis is given to the management of the obese patient with type 2 diabetes not reaching the treatment targets. With the help of all participating institutions, we expect that this consensus document will be helpful to improving the quality of diabetes care in Latin America.

Acknowledgments. The authors wish to recognize the ALAD consensus group:
Coordinators: Juan Rosas Guzman (President, ALAD), Ruy Lyra (Vice-President, Pan American Endocrinology Federation)

Participant associations (represented by): Asociación Latinoamericana de Diabetes (Juan Rosas Guzmán); Sociedad Mexicana de Nutrición y Endocrinología (Carlos A. Aguilar-Salinas and Eduardo García García); Sociedad Brasileira de Endocrinologia e Metabologia (Ruy Lyra, Marcos Tambascia); Asociación Salvadoreña de Endocrinología Diabetes y Nutrición (Carlos Alvayero); Asociación Guatemalteca de Endocrinología Metabolismo y Nutrición (Vinicio Granados); Sociedad Ecuatoriana de Endocrinología y Metabolismo (Rodrigo Rovayo Prócel); Sociedad de Diabetología y Nutrición del Uruguay (Silvia García); Sociedad Argentina de Diabetes (Gustavo Frechtel); Sociedad Boliviana de Endocrinología, Metabolismo y Nutrición (Elizabeth Duarte); Asociación Panameña de Endocrinología, Diabetes y Metabolismo (Rolando Caballero); Federación Mexicana de Diabetes (Guillermo Rodríguez); Sociedad Hondureña de Endocrinología (Mario Valdéz Laínez); Sociedad Chilena de Endocrinología y Diabetes (Carmen Gloria Aylwin); Sociedad Brasileira de Diabetes (Marilia Brito Gomes, Saulo Cavalcanti, and Antonio Carlos Lerario); Sociedad Dominicana de Endocrinología (Félix Escaño Polanco); Asociación Nicaraguence de Endocrinología, Diabetes y Obesidad (Enrique Medina Sandino); Federación Venezolana de Unidades de Diabetes (Matilde García de Blanco); Sociedad Cubana de Endocrinología (Daysi Navarro); Federación Diabetológica Colombiana (Gustavo Márquez Salom); Sociedad Peruana de Endocrinología (Isaac Crespo Retes); and Sociedad Cubana de Diabetes (Oscar Díaz Díaz).

The authors express their gratitute to Roopa Mehta for editorial assistance.

\section{REFERENCES}

1. Villalpando S, Shamah-Levy T, Rojas R, Aguilar-Salinas CA. Trends for type 2 diabetes and other cardiovascular risk factors in Mexico from 1993-2006. Salud Pública Mex. 2010;52(suppl 1):S72-9.

2. Barceló A, Aedo C, Rajpathak S, Robles S. The cost of diabetes in Latin America and the Caribbean. Bull World Health Organ. 2003;81(1): 19-27.
3. Gouvea Ferreira SR. Epidemiología de las complicaciones de la diabetes mellitus. In: Diabetes Mellitus, visión latinoamericana. Guzmán JR, Lyra R, Cavalcanti N, eds. Río de Janeiro, Brasil: Editora Guanabara Koogan; 2009. Pp. 482-94.

4. Asociación Latinoamericana de Diabetes, Organización Panamericana de la Salud, Declaración de las Américas sobre la Diabetes. Sim- posium sobre economía y diabetes. Available from: www.paho.org/Spanish/AD/DPC/ NC/dia-alad-background.pdf. Accessed 8 April 2010.

5. Arredondo A, Zuniga A. Economic consequences of epidemiological changes of diabetes in middle income countries. The Mexican case. Diabetes Care. 2004;27(1): 104-9. 
6. Guías ALAD de diagnóstico, dontrol y tratamiento de la diabetes mellitus tipo 2. Grupo de trabajo ALAD. Rev Latinoam Diabetes. 2006;14(3):96-140.

7. Ohkubo Y, Kishikawa H, Araki E, Miyata T, Isami S, Motoyoshi S, et al. Intensive insulin therapy prevents the progression of diabetic microvascular complications in Japanese patients with non-insulin-dependent diabetes mellitus: a randomized prospective 6-year study. Diabetes Res Clin Pract.1995;28(2):103-17.

8. United Kingdom Prospective Diabetes Study Group. Intensive blood glucose control with sulphonylureas or insulin compared with conventional treatment and risk of complication in patients with type 2 diabetes. Lancet. 1998;352(9131):837-53.

9. United Kingdom Prospective Diabetes Study Group. Effect of intensive blood glucose control with Metformin on complication in overweight patients with type 2 diabetes. Lancet. 1998;352(9131):854-65.

10. Nathan DM, Cleary PA, Backlund JY, on behalf of the Diabetes Control and Complications Trial/Epidemiology of Diabetes Interventions and complications Study Research Group. Intensive diabetes treatment and cardiovascular disease in patients with type $1 \mathrm{di}$ abetes. N Engl J Med. 2005;353(25):2643-53.

11. Holman RR, Paul SK, Bethel MA, Matthews DR, Neil HA. 10-Year follow-up of intensive glucose control in type 2 diabetes. $\mathrm{N}$ Engl J Med. 2008;359 (15):1577-89.

12. American Diabetes Association. Standards of medical care in diabetes 2009. Diabetes Care. 2009;29(suppl 1):S13-61.

13. Rodbard HW, Jellinger PS, Davidson JA, Einhorn D, Garber AJ, Grunberger G, et al. Statement by the American Association of Clinical Endocrinologists/American College of Endocrinology Consensus Panel on type 2 diabetes mellitus: an algorithm for glycemic control. Endocr Pract. 2009;15(6):540-59.

14. Canadian Diabetes Association Clinical Practice Guidelines Expert Committee. Canadian Diabetes Association 2008 clinical practice guidelines for the prevention and management of diabetes in Canada. Can J Diabetes. 2008;32(suppl 1):S1-201.

15. Selvin E, Marinopoulos S, Berkenblit G, Rami T, Brancati FL, Powe NR, Golden SH. Metaanalysis: glycosylated hemoglobin and cardiovascular disease in diabetes mellitus. Ann Intern Med. 2004;141(6):421-31.

16. Stettler C, Allemann S, Juni P, Cull CA, Holman RR, Egger M, et al. Glycemic control and macrovascular disease in types 1 and 2 diabetes mellitus: meta-analysis of randomized trials. Am Heart J. 2006;152(1):27-38.

17. Ray KK, Seshasai SR, Wijesuriya S, Sivakumaran R, Nethercott S, Preiss D, et al. Effect of intensive control of glucose on cardiovascular outcomes and death in patients with diabetes mellitus: a meta-analysis of randomised controlled trials. Lancet. 2009; 373(9677):1765-72.

18. Action to Control Cardiovascular Risk in Diabetes Study Group. Effects of intensive glucose lowering in type 2 diabetes. $\mathrm{N}$ Engl J Med. 2008;358(24):2545-59.

19. ADVANCE Collaborative Group, Patel A, MacMahon S, Chalmers J, Neal B, Billot L, et al. Intensive blood glucose control and vascu- lar outcomes in patients with type 2 diabetes. N Engl J Med. 2008;358(24):2560-72.

20. Duckworth W, Abraira C, Moritz T, Reda D, Emanuele N, Reaven PD, et al. Glucose control and vascular complications in veterans with type 2 diabetes. N Engl J Med. 2009; 360(2):129-39

21. Pogach L, Aron D. Balancing hypoglycemia and glycemic control. A public health approach for insulin safety. JAMA. 2010;303(20): 2076-7.

22. Johnson JA, Majumdar SR, Simpson SH, Toth EL. Decreased mortality associated with the use of Metformin compared with sulfonylurea monotherapy in type 2 diabetes. Diabetes Care. 2002;25(12):2244-8.

23. Johnson JA, Simpson SH, Toth EL, Majumdar SR. Reduced cardiovascular morbidity and mortality associated with Metformin use in subjects with type 2 diabetes. Diabet Med. 2005;22(4):497-502.

24. Cockcroft DW, Gault MH. Prediction of creatinine clearance from serum creatinine. Nephron. 1976;16(1):31-41.

25. National Kidney Fundation. K/DOQI clinical practice guidelines for chronic kidney disease: evaluation, classification, and stratification. Am J Kidney Dis. 2002;39(2 suppl 1):S1-266.

26. Bailey CJ. Metformin: a multitasking medication. Diab Vasc Dis Res. 2008;5(3):56.

27. Nathan DM. Initial management of glycemia in type 2 diabetes mellitus. $\mathrm{N}$ Engl J Med. 2002;347(17):1342-9.

28. Deeg MA. Basic approach to managing hyperglycemia for the nonendocrinologist. Am J Cardiol. 2005;96 (suppl. 1):37E-40E.

29. Inzucchi SE. Oral antihyperglycemic therapy for type 2 diabetes. JAMA. 2002;287(3):360-72.

30. Yki-Jarvinen H. Drug therapy: thiazolidinediones. N Engl J Med. 2004;351(11):1106-18.

31. Chiasson JL, Josse RG, Gomis R, Hanefeld M, Karasik A, Laakso M. Acarbose treatment and the risk of cardiovascular disease and hypertension in patients with impaired glucose tolerance: the STOPNIDDM Trial. JAMA. 2003; 290(4):486-94.

32. Palalau AI, Tahrani AA, Pilla MK, Barnett AH. DPPIV inhibitor in clinical practice. Postgrad Med. 2009;121(6):70-100.

33. Kendall DM, Riddle MC, Rosenstock J, Zhuang D, Kim DD, Fineman MS, et al. Effects of exenatide (exendin-4) on glycemic control and weight over 30 weeks in patients with type 2 diabetes treated with metfomin and a sulfonylurea. Diabetes Care. 2005;28(5): 1083-91.

34. DeFronzo R, Ratner RE, Han J, Kim DD, Fineman MS, Baron AD. Effects of exenatide on glycemic control and weight over 30 weeks in Metformin-treated patients with type 2 diabetes. Diabetes Care. 2005;28(5):1092-100.

35. Gerich J, Raskin P, Jean-Louis L, Purkayastha D, Baron A. PRESERVE-B: two year efficacy and safety of initial combination therapy with nateglinide or glyburide plus Metformin. Diabetes Care. 2005;28(9):2093-100.

36. Fonseca V, Rosentstock J, Patwardhan R, Salzman A. Effect of Metformin and rosiglitazone combination therapy in patients with type 2 diabetes mellitus. JAMA. 2000; 283(13): 1695-702.

37. Strowig S, Aviles-Santa ML, Raskin P. Improved glycemic control without weight gain using triple therapy in type 2 diabetes. Diabetes Care. 2004;27(7):1577-83.

38. Pontiroli AE, Calderara A, Pacchioni M, Cassisa C, Pozza G. Weight loss reverses secondary failure of oral hypoglycaemic agents in obese non-insulin-dependent diabetic patients independently of the duration of the disease. Diabete Metab. 1993;19(1):30-5.

39. Bloomgarden ZT. Approaches to treatment of pre-diabetes and obesity and promising new approaches to type 2 diabetes. Diabetes Care. 2008;31(7):1461-6.

40. Genuth S: Insulin use in NIDDM. Diabetes Care. 1990;13(12):1240-64.

41. Raskin P, Allen E, Hollander P, Lewin A, Gabbay RA, Hu P, Bode B, Garber. Initiating insulin therapy in type 2 diabetes. Diabetes Care. 2005;28(2):260-5.

42. Yki-Jarvinen H, Ryysy L, Nikkila K, Tulokas T, Vanamo R, Heikkila M. Comparison of bedtime insulin regimens in patients with type 2 diabetes mellitus. Ann Intern Med. 1999;130(5):389-96.

43. Schwartz S, Sievers R, Strange P, Lyness WH, Hollander P. Insulin 70/30 mix plus Metformin versus triple oral therapy in the treatment of type 2 diabetes after failure of two oral drugs. Diabetes Care. 2003;26(8);2238-43.

44. Welschen LM, Bloemendal E, Nijpels G, Dekker JM, Heine RJ, Stalman WAB, Bouter LM. Self monitoring of blood glucose in patients with type 2 diabetes who are not using insulin: a systematic review. Diabetes Care. 2005;28(6):1510-17.

45. Lopez Stewart G, Tambasia M, Rosas J. A Multi-Center, Epidemiologic Survey of the Current Medical Practice of General Practitioners Treating Subjets with type 2 Diabetes Mellitus In Latin America. DEAL STUDY. Diabetes. 2007;56 (suppl1):A 256.

46. Jimenez Corona A, Rojas Martinez R, GómezPérez FJ, Aguilar-Salinas CA. Early onset type 2 diabetes in a Mexican, population-based, nation-wide survey: results of the Encuesta Nacional de Salud y Nutrición 2006. Salud Publica Mex. 2010:52(supl1):S27-S35.

47. Aguilar Salinas CA, Gomez Pérez FJ. La declaración de Acapulco. Rev Invest Clin. 2006; 58(1):71-7.

48. Nathan DM, Buse JB, Davidson MB, American Diabetes Association, European Association for the Study of Diabetes. Medical management of hyperglycemia in type 2 diabetes: a consensus algorithm for the initiation and adjustment of therapy; a consensus statement of the American Diabetes Association and the European Association for the Study of Diabetes. Diabetes Care. 2009;32(1): 193-203.

49. Guías ALAD recomendadas por OPS. Available from: http://www.paho.org/spanish/ $\mathrm{ad} / \mathrm{dpc} / \mathrm{nc} /$ dia-guia-alad.htm. Accessed 8 April 2010

Manuscript received on 19 July 2010. Revised version accepted for publication on 5 November 2010. 
RESUMEN América Latina se enfrenta a algunos retos excepcionales en el tratamiento de la diabetes mellitus tipo 2. La Asociación Latinoamericana de Diabetes (ALAD) reunió a las asociaciones médicas de 17 países latinoamericanos con el fin de producir una decla-

Tratamiento de la diabetes tipo 2 en América Latina: declaración de consenso de las asociaciones médicas de 17 países latinoamericanos

Palabras clave ración de consenso sobre el tratamiento de la diabetes tipo 2. El objetivo de ese documento es brindar recomendaciones prácticas que guíen a los médicos a lo largo de un sencillo proceso decisorio para el tratamiento de los pacientes. Los elementos fundamentales para la toma de decisiones terapéuticas son la gravedad de la hiperglucemia, el estado clínico del paciente (estable o con descompensación metabólica) y el índice de masa corporal. El documento contiene un apartado dedicado específicamente a los pacientes obesos y la información se presenta en forma de preguntas clínicas sumamente pertinentes. El algoritmo se basa en las recomendaciones científicas de las directrices de la ALAD del año 2006 (documento preparado con un método basado en datos probatorios) y en datos obtenidos de estudios controlados aleatorizados recientes.

Diabetes mellitus tipo 2; obesidad; consenso; guías de práctica clínica como asunto; América Latina. 